\title{
BOULES DE SENSATIONS-PENSÉES-FORMES IN CHRISTOPHE TARKOS'S POETRY
}

JEFF BARDA

In the genealogy of recent French contemporary poets who have risen to the challenge of experimenting with 'une nouvelle conception des enjeux du langage poétique', ${ }^{1}$ Christophe Tarkos (1963-2004) occupies a prime position. Tarkos is not only known in France and abroad for his astonishing performances, unique improvisation and sense of humour but also for his editorial commitment: he edited several significant journals such as Facial, R.R and poézie proléter which published amongst others Charles Pennequin, Nathalie Quintane and Katalin Molnár; and played a significant role in the poetic renewal of the $1990 \mathrm{~s}^{2}$ Even though Tarkos's life was tragically cut short in 2004, at the age of forty-one, when he was diagnosed with a brain tumour, he published more than eleven volumes of poetry and enjoyed a considerable reputation amongst older writers (Jean-Marie Gleize, Christian Prigent, Jacques Sivan) and his contemporaries (Jean-Michel Espitallier, David Christoffel, Jérôme Game). ${ }^{3}$ His work represents a moment in France where the aesthetic super ego was not only reduced to the revival of lyricism, a tradition repressed by the avant-garde model of the 70s in France, but also to what Pierre Alferi and Olivier Cadiot termed ironically 'la tête de Queneau sur le corps d'Artaud'. Many poets felt trapped by history and the commonplaces of modernity to the extent that hopes for a true and innovative poetic project had been crushed. This period, indeed, signalled on the one hand the permanence of notions of 'suffering', 'lack' and the 'impossible' epitomized by the tutelary figures of the French avant-garde (Georges Bataille, Jacques Lacan, Maurice Blanchot) finding its illustration in the fiery and provocative writings of Valère Novarina, Pierre Guyotat and Jean-Pierre Verheggen; on the other, the formalism of the OuLiPo was not spared from these critiques and poetic models and postures. Indeed, as Emmanuel Hocquard suggests:

Comment des notions comme celles de manque, de défaut, d'absence, d'impossible, prise naguère à la lettre, en arrivent-elles à se transformer en clichés rhétoriques? Les 
inventions formelles en jeux esthétiques? Comment la biscotte sans beurre se met-elle à dégouliner à nouveau de nostalgie, d'émotion, de souffrance, bref de psychologisme, de complaisance et de narcissisme? [...] Comment y échapper? ${ }^{5}$

In the 90s an entire generation of poets, including Anne Portugal, Suzanne Doppelt, Olivier Cadiot and Pierre Alferi, felt hampered by these approaches and devoted themselves to an opposite theoretical model. Firstly, they replaced the doctrine of negativity with another kind of constructivism which considered creative thought as no longer a response to lack, but to desire. ${ }^{6}$ Secondly, they substituted techniques for Oulipian constraints and the toolbox (a set of tools used for specific functions and purposes directed towards a definite end beyond their own existence and form) for the programme (a mechanical and systematic set of rules). In their two influential volumes of the Revue de littérature générale, in which Tarkos took part, Cadiot and Alferi offered a remarkable inventory of techniques of heterogeneity (cut-up, permutation, loops, sampling) and illustrated these. Essentially materialist, this approach which forcefully rejected the notions of genius, absolute meanings, teleological ends and lyricism, favoured a principle of composition based on the manipulation and grafting of pre-existing pieces of language and subjective understanding of poetic creation. These texts - 'hétérogènes [...] monstres construits autour d'un noyau composite, monstres résultant de la greffe, de membres dépareillés ${ }^{7}$ - were termed by Alferi and Cadiot as 'Ovni' whose play on words both refer to their uniqueness ('Objets Verbaux Non Identifiés’) as well as peculiarity (Ovni is the French synonym for UFO). This constructivist and materialist conception of writing sought to reverse the lyrical dialectic (narcissism/emotion) to another type of conception of writing based on a constructivist approach (objectivity/construction):

Ce dont la fiction a besoin, c'est d'un matériau de construction spécifique: des boules de sensations-pensées-formes. [...] On peut les appeler Objets, parce qu'ils sont manufacturés et qu'ils doivent pour servir être tous de niveau. [...] Ils résultent déjà d'un travail, mais ils ne seront que des chevilles ouvrières transitoires, peu visibles. Car leur nature n'est rien d'autre que leur fonction. ${ }^{8}$ 
This desire to develop language as a connective synthesis of different attributes - material, physical and mental - which emerges when language is treated as a material of construction finds a strong resonance in Tarkos's poetry. He construes this process in material and organic terms through the recurrent image of 'pâte-mots', an image which reflects the way language, thought and sensation take shape. This poetic project, as we shall soon see, is characterized by a conglomerate of circular utterances, made up of permutation and a singular stuttering as constitutive features of thought. In this article, I argue that Tarkos invents a poetry of sensation in which the self is no longer defined as consubstantial with poetic expression as either a hole (Samuel Beckett) or an abyss (Henri Michaux), but as a 'boule' ${ }^{9}$ that is a mobile individuation defined as a nexus of intensities and differences of nature that reject all forms of identification or stable entity. This organic self released from the idea of an absolute interior (doubts, metaphysics, angst) conveys a conception of language and of the real which rejects transcendence, depth or concepts and provides a new definition of the poetic subject.

In several texts, Tarkos defines poetic language in material terms through the recurrent image of 'pâte-mots' (dough of words). This kneading process that can be shaped and reshaped continually is a constructivist metaphor of the poetic work that reflects the becoming of language:

Pâte-mot, c'est comme ça que je travaille, [...] la pâte faite de mots. Ce qui signifie qu'on n'a pas comme ça des petits fragments pour parler, mais on n'a que des choses qui sont collées les unes avec les autres, comme quand on dit, fait une expression, on a une expression, on dit un groupe de mots qui n'ont pas tellement de sens isolément, mais c'est tout un ensemble [...]. Elle peut bouger comme une méduse, elle peut bouger d'un côté et de l'autre, respirer [...]. Pâte-mot repose sur l'élasticité du des sensations, [...] ce qui signifie qu'il ne sera plus possible d'espérer qu'un mot survive longtemps dans l'air libre, il en mourrait, il retombe, [...] il n'y a pas de raison d'aller loin sans figures, sans sautillements, sans piquants, sans sauts, là où se trouve la productivité de la pâte face à sa confrontation $[\ldots] .{ }^{10}$ 
For Tarkos, writing consists of manipulating compact linguistic residues into new order to create effects. This dough is able to combine and embrace heterogeneous sediments whilst rejecting hierarchies: these range from 'jeux de mots idiots' and slogans to 'les phrasés, de la phraséologie, des phrases'. ${ }^{11}$ This amorphous material is also characterized by its plasticity and malleability ('c'est une parois élastique', ${ }^{12}$ 'coulante, molle', ${ }^{13}$ 'visqueuse, ${ }^{, 14}$ ), one that rejects fixed identities or solidification in favour of a texture that can be infinitely kneaded. This is why Tarkos attributes a central importance to physical reality, understood as knowledge of laws since it deals with states of motion, i.e. differences of level, that include 'sauts', 'sautillements' and 'retombée'. This poetic model, which relies on an organic model of fermentation (yeast), is a symbiotic one in which an agent gives rise to the upsurge of a phenomenon based on a reactive force that propels language away. If at first sight, this image reminds us of Ponge's seminal poem 'le pain', Ponge remains an important landmark for many anti-lyric poets engaged in a strict embargo on subjectivity, reference and endless fascination for prosaic objects, ${ }^{15}$ Tarkos's model is contrary to the stellar and panoramic Pongian bread, ${ }^{16}$ analogous to the 'Soap':

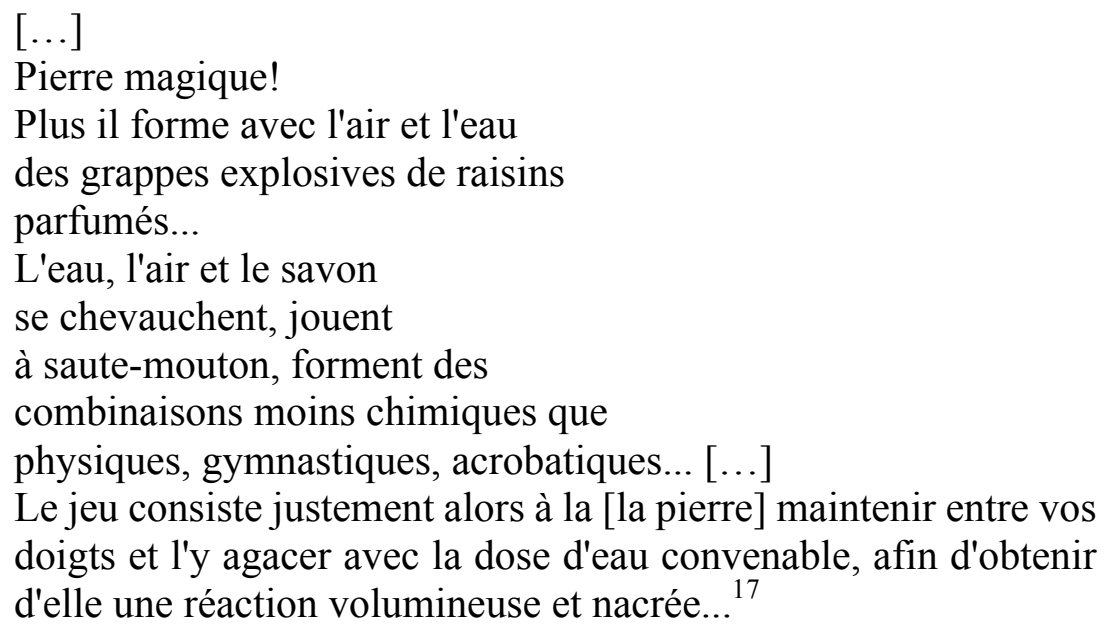

Friction between air, water and the soap gives rise to the emergence of particular 'grappes explosives de raisins', combinations emanating from motion ('physiques, gymnastiques, 
acrobatiques'), space ('réaction volumineuse') and chance ('se chevauchent, jouent, à saute mouton'). While for Ponge, soap is associated with a malleable process that subsequently rests on synaesthesia and a game ('le jeu consiste justement...'), Tarkos substitutes compactness for space, concentration for dispersion, tension for evaporation ('c'est très très serré', 'les mots sont regroupés en une masse indistincte pour pousser une petite poussée de sens [...] il faut que tous les mots à la fois s'y fassent pour faire un effet'). ${ }^{19}$ The interplay of materials gives rise to effects of velocity in which language is suddenly traversed by intensities and flux: spaced intervals as well as degrees of acceleration. Evoking this movement, Tarkos, like Alferi, defines the essential energy of writing in Spinozian terms, referring to the 'élan': 'la description s'en tient aux formes d'un élan, la phrase le met en scène [...] l'élan est lui-même excessif, démesuré, $[\ldots]$ élan infini $[\ldots]$ retombe alors de lui-même dans la mesure' ${ }^{20}$ And yet, this 'élan' is necessarily indeterminate: 'chaque phrase l'affirme, l'explique, l'arrête, le relance'. ${ }^{21}$ Tarkos's poems chart a jagged line of fluid rebounds, jumps and skids that carry away semantic, syntactical and rhythmic relations in the process:

Le sens ne va pas pour une fois, ne va pas en une fois, va s'y reprendre à plusieurs fois n'est pas sûr, n'est pas rassuré de devoir passer la matière pour, la matière carrée, la matière fixée, pour réussir une pirouette en l'air, pour réussir à se retourner, pour ensabler, pour ensemencer, pour regrouper tout ce qui se passe, ce qui passe vite en une seule poussée, en une seule matière, en une fois [...] le sens [...] comment pourrait-il en une fois se carrer? ${ }^{22}$

For Tarkos, the original act of nomination is the product of a contingent temporal process. Saturation of infinitives and prefixes, such as 're' ('reprendre', 'retourner', 'regrouper') and 'en' ('ensabler', 'ensemencer') performs the incremental motion of things illustrating the strict rejection of formal solidification ('la matière carrée') and meaning ('comment pourrait-il en une fois se carrer?'). In this context, the eliciting of meaning depends on a temporal mode that refers to Aiôn instead of Chronos, ${ }^{23}$ to the Deleuzian definition of the Stoic notion of time as 
the dispersion of events and becomings rather than linearity, causality and finitude. In rejecting formalism, Tarkos maintains the idea of a text that projects, deconstructs and reconstructs forms and meanings:

De là un point de poussée en étirant un peu un endroit qui soit un point de poussée à partir duquel s'étire un point un point de départ d'où en tirant un peu un endroit vivable pour être la base de départ où commencer en étirant un premier commencement qui, en bougeant, permette un premier retournement avec assez de place en étirant pour être un endroit où pourraient se mouvoir des choses très abstraites qui ne prennent pas de place pour à partir de là un point en étirant qui servirait de départ pour un endroit où il serait possible de trouver une méthode pour rechercher un endroit où il serait possible de penser. ${ }^{24}$

Poetry is thus all about the beginning of a process ${ }^{25}$ ('départ', 'commencement') rather than a teleology in which the effects of contiguities and agglutination, through language, are played out. ${ }^{26}$ For Tarkos, the poem is an organic compound of words that forms strings of connecting 'points' to the extent that each utterance gives the impression of generating the text: 'un point de poussée' merges into 'un point de départ', and 'un point en étirant' culminates in 'la base de départ'. The impossibility of finding 'un endroit', that is a means of stabilizing shapes, motion and thought in space is suggested by the numerous polyptotons ('commencer', 'commencement'; 'étirer', 'étirant') which creates a dynamic line constituted by deviations, curves and rebounds that affect both syntax and meaning. Close to Lucky's famous monologue from En attendant Godot, whose discourse locks in forethought and stumbles over obstacles whilst parodying a rhetorical exercise to prove the existence of God through metaphysics, Tarkos's poem appears as an ironic 'Discourse on the Method'27 ('une méthode pour 
rechercher/un endroit où il serait possible de penser') deprived of metaphysical meditations, causality, discursive organisation or a definite site:

La vraie vie est d'avoir une voiture amie vivre est vivre avec une voiture amie il est vrai que la vraie vie est d'avoir avec soi une voiture une voiture amie que c'est vivre en vie avec une voiture amie de vivre avec avec une voiture à soi avec une voiture amie avec une vraie voiture à soi voilà la vraie vie. ${ }^{28}$

While poetic language usually stands in stark contrast to ordinary credulities where prevailing narratives are accepted, Tarkos experiments with ill formed utterances ('la vraie vie') to let the reader contemplate their contour and indeterminacy whilst creating a singularly stuttering expression, opening language to infinite modulations and reflexivity. Not only does the excision of punctuation pile up ready-made utterances while eliminating logical relationships between words, but it also forecloses any possible differentiation, thus rendering each segment interchangeable ('vie' is 'voiture' but also 'amie'). Unlike Beckett's psittacism, which consisted in digging holes within language wholes by adding words to the middle of the sentence ('il est établi tabli tabli ce qui suit qui suit qui suit'), ${ }^{29}$ and Luca's pathological stuttering ('t'aime aime aime je t'aime/passionné é aime je/t'aime passioném/je t'aime/ passionnémen' $)^{30}$ which is characterized by an impossibility to say everything all at once, ${ }^{31}$ Tarkos's poetics does not rely on segmentation, the abolition of the thetic or metamorphosis. Rather, his ritornelli replace the false expectations for progression, as if speech were suddenly reduced to a conglomerate of repeated utterances running out of perspectives ('voilà la vraie vie').

Language is characterized by circular phrasings that reflect a lack of causality and perspective, yet redefine their sites in the process: the material figuration of language refers only to itself, refusing all transcendence in favour of a sur-face. This approach conveys an immanent conception of poetry in which language is reduced to its simplest expression: 'brut 
et non épais le poème à plat exactement étalé/sous les yeux dans toute sa longueur y/s'embrasse pas d'intérieur le tout nu sans apprêt'. ${ }^{32}$ Instead of resorting to rhetorical emphasis and poetic devices to inchoate meaning or generate images, Tarkos favours a poetics with no shades ('brut', 'sans apprêt'), differences ('non épais') and depth ('à plat' and 'nu', 'étalé'). This approach to language stands in stark contrast with the condition of 'illisibilité', ${ }^{33}$ characteristic of avant-garde writing, which played the role of a device criticizing the constitutive principles of western rationality. As opposed to this model, Tarkos notes:

Le texte est lisible. Il est facile à lire, il est rythmé, il respire, il court bien. Le texte est clair, il se poursuit avec enchaînements, il se lit bien, on suit aisément l'histoire [...] Le texte se lit facilement, il n'y a pas de difficulté majeures, d'idées mal maîtrisées et on suit aisément l'histoire. ${ }^{34}$

Rather than opacity as an essential quality of avant-garde writing, what is praised here is the vow of literality - that is, an approach to language which consists of rejecting the deciphering of material entities by representing the world as it is, detached from its concepts or mediations. The idea of a 'poetics of idiocy' is a characteristic common to many poets of this generation. ${ }^{35}$ As Jean-Marie Gleize suggests, this type of poetry 'serait littéralement littérale, elle voudrait dire ce qu'elle dit en le disant en l'ayant dit et la prose en prose comme poésie après la poésie [...] n'aurait littéralement, proprement, aucun sens que le sens idiot de dire ce qui est., ${ }^{36}$ In this respect, if being literal suggests rejecting the idea that poetry could reveal a beyond, literality reactivates the original meaning of 'idios ${ }^{37}$ referring to the one able to perceive the singularities of each things without equivocity. This model, however, reveals a certain activity of consciousness that gives the impression that things are solely seen from the inside and no exteriority seems possible:

Je suis blanc, je suis tout blanc. Je ne sais plus ce que ma pensée pense. Je ne comprends plus ce qu'elle veut penser, ce qu'elle pense, si ce qu'elle pense est juste ou non, est bon 
ou mauvais ou autre chose, je suis entièrement blanc, je ne peux plus juger de ma pensée, je ne pense sans pouvoir savoir, elle peut se penser ce qu'elle veut, je suis blanchi, je n'ai plus aucun moyen de savoir ce qu'elle est, ce qu'elle veut, je ne peux plus la juger, je ne la juge pas, elle fait ce qu'elle veut, elle me détache, je ne juge plus, je ne sais plus ce qu'elle pense, comment elle pense, elle pense sans que je puisse juger, de son côté elle peut bien penser ce qu'elle veut, je n'ai plus de regards sur ma pensée, je suis tout blanc, je ne sais plus maintenant ce que je fais, ma pensée me devance, elle est loin devant, elle est laissée, elle se balance comme elle l'entend, je suis entièrement blanchi, dire si ce qu'elle pense est juste est fini, je ne juge plus, elle pense, je suis entièrement blanc, je suis d'une grande blancheur. ${ }^{38}$

While Mallarmé claimed that 'ma Pensée s'est pensée'39 and revealed how all thought emits a throw of a dice, Tarkos is incapable of securing any foundation of certainty or to consider subjective knowledge as the most reliable entity ('Je ne sais plus ce que ma/pensée pense’; ‘je ne/peux plus juger de ma pensée’; ‘je ne/peux plus la juger, je ne la juge pas, elle fait ce qu'elle veut'). Everything here suggests an eradication of subjectivity as emphasized by the passive voice ('ma pensée me devance, /elle est loin devant, elle est laissée, elle se balance comme/elle l'entend'). There is a reversal between thought/consciousness: thought no longer depends on consciousness but consciousness stems from thought and independently of a reference to an object. Consciousness is the result of a succession of ideas generated from each other and originating in thought. This consciousness is characterized by an incapacity to go beyond surfaces as if the world were reduced to pure sensations. This pathogenic attitude to deal with exteriority gives the impression of a recurring temptation to go round and round in circles, almost tautologically:

Sur un coussin sur un sofa. Un coussin sur les coussins du sofa. Un petit coussin, on peut dire un coussinet. Un coussin à peu près marron sur le sofa. Un bon coussin en fin de compte. Avec tout ce qu'il faut à un coussin pour faire un bon coussinet rectangle. Un coussin rebondi. Un coussin rebondi comme l'oreiller peut l'être aussi. Et mœlleux. Un coussin mœlleux [...]. ${ }^{40}$ 
Rather than a progression in reasoning, this consciousness is marked by an absence of the distance normally conducive to the drawing of a conclusion. Instead of revealing the content of things, solely the contour is unfolded ('un petit coussin', 'à peu près marron', 'rebondi'). Furthermore, language reduces entities to isomorphic relations ('Un coussin rebondi comme l'oreiller/peut l'être aussi'), abolishing all forms of surprise or novelty. Equality and a lack of differences between entities characterize Tarkos's 'prose of the world' which constantly generates a specific type of what Barthes calls 'autonymy', i.e. an auto-designation and autoreferentiality of a noun, defined as 'le strabisme inquiétant (comique et plat) d'une opération en boucle, quelque chose comme [...] une surimpression inversée, un écrasement de niveaux' ${ }^{41}$ In reality, this idiotic poetry attempts to unfold not abstraction but the concrete singularities (peculiar as well as unique) of each thing, while remaining detached from any affection, as suggested by the following organic image of milk:

Il y a du lait partout. Il y a du lait dans le beurre. Des litres de lait blanc se trouvent partout. Il y a du lait dans tous les bons produits. Du lait partout. Il y a du lait dans le beurre et dans la crème. Des litres de lait blanc dans les tonneaux et dans les camionsciternes. Ce sont des litres de lait versés dans les biscuits, et dans les barres chocolatées, et dans la pâtisserie industrielle, le lait est des formes variées. Le lait est partout. Des litres de lait blanc versés. Le lait dans la forme des tonneaux et des tonneaux de litres de poudre. Le lait est en poudre. C'est le lait sec en poudre qui se trouve partout. Le lait blanc des paquets de beurre, de la pâte et des sauces et de la crème et de la garniture et du gout. Il y a du lait partout, dans les champs, les tire-lait à roues, les vaches et les vachers, sur les routes, les charrettes de bidons de lait. Le lait est blanc. Il y a du lait blanc pour les beurres, pour la purée de pommes de terre, pour les poudres de céréales à diluer dans le lait. Il y a dans tout un peu de lait. Le lait est partout, dans la purée de pommes de terre en poudre et dans la poudre et dans le chocolat au lait, il y a de la poudre de lait. Il y a du lait partout. Avec le lait dans des gâteaux, dans les barres chocolatées et tout le fromage. Il y a des bidons et des tonneaux et des citernes de lait qui versent. Le lait est dans toutes les formes, en poudre de lait dans les biscuits, des litres de lait blanc liquide dans les yaourts. Le lait est blanc, il y a du blanc lait partout. Le lait est lui-même dans les brioches et dans la béchamel et dans le beurre. Il y a du lait dans la brioche et la béchamel et le beurre. Le lait est dans tout. ${ }^{42}$

Here the substantive 'lait' plays the role of nucleus whose spiral-like swirling envelopes neighbouring syntagms emphasizing the transformational nature of milk, ${ }^{43}$ ranging from liquid 
('lait versé') to solid ('en poudre', 'lait sec') whilst begetting new associations ('yaourt', 'brioche', 'béchamel', 'beurre' and 'chocolat'). At the same time, this apparent totality ('tout') shows that milk literally leaks everywhere ('partout') foreclosing any possible differentiation, rendering these attributes interchangeable, as each replaces the other ('le lait dans la forme des tonneaux et des tonneaux de litre poudre'). Literality thus stands against the flamboyant expression of lyrical poetry, the infra-linguistic use of language epitomized by the minimalist aesthetic of the 70s 'poésie blanche', and the carnivalesque cadences of post-Tel Quel poetics. ${ }^{44}$ As Tarkos suggests: 'Nous allons au-delà du mutisme, nous/ dépassons le mutisme, pour atteindre le faire/ face [...] cela est le premier/ mouvement littéraire d'après d'au-delà du/mutisme [...]'. ${ }^{45}$ Between silence and clamour, Tarkos prefers the transformation of language into a monochordal, a-lyrical continual flux capable of capturing the singularities of each thing. ${ }^{46}$

What was it that motivated Tarkos, in his reference to Saussure, to claim ironically, in Le Signe=, that 'le signifié = le signifiant'? ${ }^{47}$ Clearly, there is no Cratylist nostalgia of a nonarbitrary relationship between the signifier and the signified in which all verbal signs would be motivated (even though some texts ironically entail a mimological function), ${ }^{48}$ of a reestablishment of the figural dimension of language to emotional values. The true risk of such a programme would be a reactivation of the embodiment of thought and sensation and a return to past avant-garde models. Indeed, the view that a certain use of language signifies the writing of the body itself was anchored in significant poetic and theoretical developments of French poetry across the twentieth century. The emphasis of the French avant-garde, from Artaud to Guyotat, on the motivation of the linguistic sign, through linguistic distortions, reflected what Prigent termed the "“voix-de-l'écrit", la trace sonore et rythmique du geste appelé "écriture"”. ${ }^{49}$ Such a conception of language sought to show how sounds represent symptoms symbolizing emotions analogically. ${ }^{50}$ The repetition of phonemes and glossolalia in their work elicit a fiery and 
provocative form of writing, cultivating a taste for pornography and scatology through which certain emotions of excitement, estrangement and 'jouissance' are expressed. In the 60 s sound poets and practitioners of 'l'art corporel' clearly state their affiliations with Artaud and Bataille, envisaging the body as a material conduit to states of rapture and ecstasy. In one of his manifestos on body art, Michel Journiac for instance emphasized how the body is a space of the interrogative relationship between the self and the world. ${ }^{51}$ Instead of reactivating an energetic state prior to language, this privileging of the body appeared for these artists both as a means of rejecting the conspicuous consumption of intimate experience that triumphed in commerce. Tarkos forcefully rejects the idea that the body is a vector of the visceral performance of language, rebelling against these phenomenological models that reduce the ontology of the subject to a fleshy body in which differences, modulations and confrontations with outside combine. By coining 'poésie faciale' as opposed to 'poésie corporelle', Tarkos refuses the idea that poetry could reveal the essence of being or restore a genuine experience of what is considered inexpressible. In doing so, Tarkos sets aside all naiveté with regard to the expressivity or singularity of a voice by substituting the facial for the embodied and extolling a split between the body and the text: ${ }^{52}$

J'écris sur la lecture pour qu'en lisant on sache que c'est un texte sur ce que l'on est en train de faire puis je lis à haute voix ce que j'ai écrit ou ce que je n'ai pas encore écrit qui me traverse la tête pour faire ce qu'un texte fait sans l'écrire, mais cela seulement lors d'une lecture publique à haute voix où je ne suis pas obligé de lire alors je ne parle pas de la lecture, je lis dans ma tête sans feuilles. ${ }^{53}$

The split between text/body is made clear by Tarkos: poetic discourse neither emerges from any predetermined set of rules nor from any material reality whether textual or corporeal but from a mental process ('la tête', 'je lis dans ma tête') rather than from a pulsional basis. As a result, Tarkos repudiates the material presence of the text in favour of the hic et nunc suggesting that the working of the mind is analogous to the mechanisms of a text ('la tete pour faire ce 
qu'un texte fait sans l'écrire', 'je lis dans ma tête sans feuilles'). This statement shows that there is not an interrogation between an internal horizon of the thing and an external one of the world, but an immanent dialogue between the self and itself. Sensation neither originates from a synthesis of perspectives between a situated point of view in time or from a project, nor from any material reality. This constant attention to impression and sensation rather than intellection, on immediacy and spontaneity rather than on inference or calculation, characterizes a certain unity of the subject in which 'tout se passe dans l'esprit à un niveau qui n'est ni technique ni linguistique'. ${ }^{54}$ Such a paradigm, however, should not be conflated with Surrealist improvization (psychic automatism) ${ }^{55}$ following the dictation of thought in the absence of reason enabling the representation of the dream-work, its condensation and displacement. What is left is a surface that does not open to any depth or interiority but to a certain immediacy of the moment. ${ }^{56}$ Like Spinoza's definition of 'spiritual automaton', Tarkos's poetry shows that ideas differ from psychological consciousness since they obey a certain autonomy that has an efficient cause in the attribute of thought:

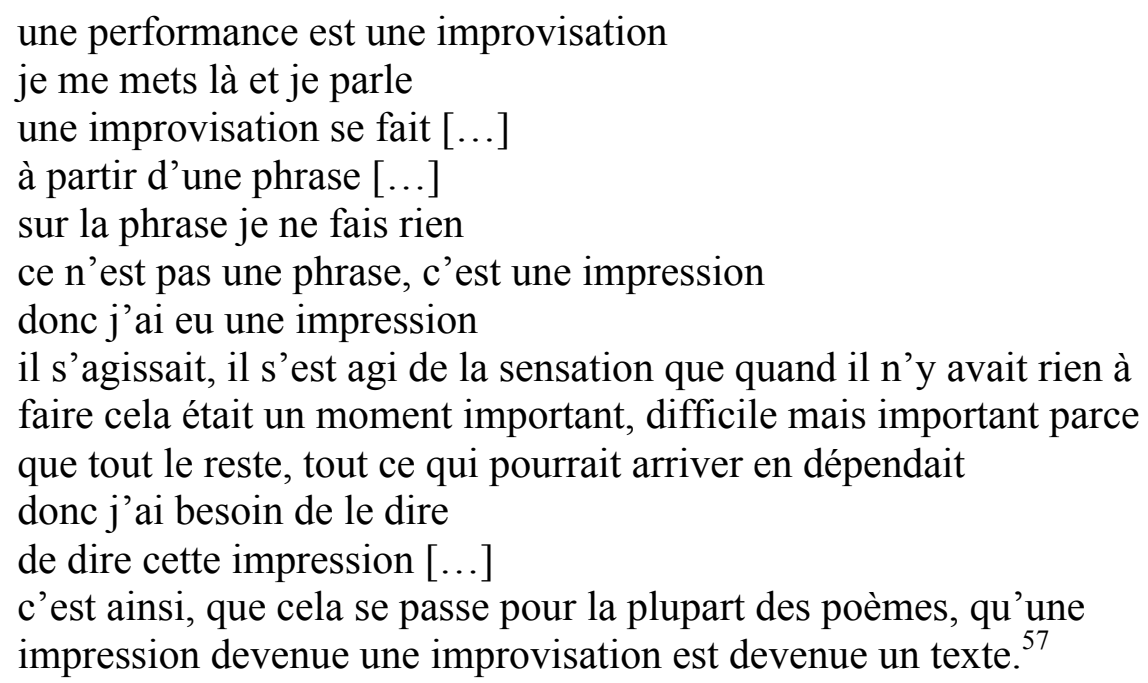

This spiritual automaton, as opposed to the traditional definition of a self-operating machine following mechanical operations, reveals the becoming of the thought ('je me mets là et je parle, une improvisation se fait'). Tarkos's emphasis on the word 'impression' can be here 
understood at least in two senses: on the one hand, it metonymically reflects an image of thought in which sensation is a stimulus prior to language; on the other hand, it suggests that reality can only be perceived by its surface rejecting all depth in favour of the becoming ('une impression devenue une improvisation est devenue un texte'). What this poetry reveals is that thought and sensation elicit an ability to be moved by themselves (auto-maton) and that thought with its laws and specific modes of actions is independent from all material entity such as the body or the text. Thought acts by itself without the aid of the body but follows its proper determinations. This reflexive consciousness and lack of perspective show that the self is a pure becoming, a bloc of sensation, defined as a cause of itself beyond any relationship to an external referent: 'La sensation se forme en contractant ce qui la compose, et en se composant avec d'autres sensations qu'elle contracte à leur tour. [...] C'est par contemplation qu'on contracte, se contemplant soi-même à mesure qu'on contemple les éléments dont on procède. ${ }^{58}$ This process reveals a certain actualization of thought in which language neither seeks to decipher the essence of things, nor to recreate the world, but to apprehend transformations of reality on a purely immanent plane. It rests on a facing up, a 'tout ce qui pourrait arriver', a formula echoing Manet's 'tout arrive', ${ }^{59}$ i.e. a becoming whose advent is itself the essence of the event. Rejecting the traditional dualism between mind/body, Tarkos's poetry shows that thought follows autonomous laws that reflect an expressive content of ideas and a specific mode of action in the world: he substitutes for the ontological and stable model of the ego, the 'boule', that is to say, the process and infinite deployment of self released from the illusion of sovereignty.

\footnotetext{
${ }^{1}$ Christian Prigent, 'Sokrat à Patmo', in Christophe Tarkos, Écrits poétiques (Paris: P.O.L., 2008), p. 12.
} 
${ }^{2}$ See for instance, Eric Loret, 'Mort de Christophe Tarkos, héraut de la nouvelle poésie', Libération, 3 December 2004, <http://next.liberation.fr/culture/2004/12/03/mort-dechristophe-tarkos-heraut-de-la-nouvelle-poesie_501561> [accessed 5 December 2016]. ${ }^{3}$ On this question, see the recent special issue and festschrift on Tarkos, 'Tarkos', Cahier Critique de Poésie, 30 (Marseille: CipM, 2015).

${ }^{4}$ Pierre Alferi and Olivier Cadiot, Revue de littérature générale, Digest 96/2 (Paris: P.O.L., 1996), section 49, n. p.

${ }^{5}$ Emmanuel Hocquard, Ma haie (Paris: P.O.L., 2001), p. 27.

${ }^{6}$ This statement echoes Deleuze's critique of lack as a counter-effect of desire: 'Si le désir est manqué de l'objet réel, sa réalité même est dans une "essence du manque” qui produit l'objet fantasmé. Le désir ainsi conçu comme production, mais production de fantasmes, a été parfaitement exposé par la psychanalyse. [...] Mais même quand le fantasme est interprété dans toute son extension, non plus comme un objet, mais comme une machine spécifique qui met en scène le désir, cette machine est seulement théâtrale, et laisse subsister la complémentarité de ce qu'elle sépare: c'est alors le besoin qui est défini par le manque relatif et déterminé de son propre objet, tandis que le désir apparaît comme ce qui produit le fantasme et se produit luimême en se détachant de l'objet, mais aussi bien en redoublant le manque, en le portant à l'absolu, en en faisant une "incurable insuffisance d'être", un "manque-à-être qu'est la vie". D'où la présentation du désir comme étayé sur les besoins, la productivité du désir continuant à se faire sur fond des besoins, et de leur rapport de manque à l'objet (théorie de l'étayage) [...]. Le manque est un contre-effet du désir, il est déposé, aménagé, vacuolisé dans le réel naturel et social' in Gilles Deleuze and Félix Guattari, L'Anti-CEdipe (Paris: Minuit, 1972), pp. 33-5.

${ }^{7}$ Alferi and Cadiot, Revue de Littérature générale, Digest, section 49, n.p.

${ }^{8}$ Pierre Alferi and Olivier Cadiot, Revue de littérature générale, la mécanique lyrique (Paris: P.O.L., 1995), p. 5. 
${ }^{9}$ See my article, 'Le Moi-boule', in Art Press, 420 (2015), pp. 80-81.

${ }^{10}$ Christophe Tarkos, 'Pâte-mot discussion' in Fusées, 15 (2009), p. 7.

${ }^{11}$ Philippe Castellin, 'Le Poète se tombe', in Action poétique, 179 (2005), p. 13.

${ }^{12}$ Christophe Tarkos, Le Signe= (Paris: P.O.L., 1999), p. 15.

${ }^{13}$ Ibid., p. 46.

${ }^{14}$ Ibid., p. 46.

${ }^{15}$ See Ponge, résolument, ed. by J.-M Adam and J.-M Gleize (Lyon: ENS Éditions, 2004).

${ }^{16}$ While Ponge in 'le pain' explores a cosmology of articulated associations ('ces plans si nettement articulés') ranging from the Alps to flowers, Tarkos rejects all forms of unity in favour of dispersion and a clear lack of articulation. Like Pound's vortex, Ponge's soap and Tarkos's dough is a matrix that generates a proliferation of particulars, an agglomeration of singularities.

${ }^{17}$ Francis Ponge, Le Savon (Paris: Gallimard, 1967), p. 19.

${ }^{18}$ Tarkos, Le Signe=, p. 18.

${ }^{19}$ Tarkos, 'Patemot' in Nioques, 1.2 (1996), p. 122.

${ }^{20}$ Pierre Alferi, Chercher une phrase (Paris: Bourgois, 2007), p. 28.

${ }^{21}$ Ibid.

${ }^{22}$ Tarkos, Le Signe=, p. 20.

${ }^{23}$ See Gilles Deleuze, 'Du jeu idéal' in Logique du sens (Paris: Minuit, 1969), pp. 74-82 (pp. 80-1).

${ }^{24}$ Tarkos, Écrits poétiques, p. 46.

${ }^{25}$ It is the title of an important text by Tarkos. See 'Processe' in Écrits poétiques, pp. 61-159.

${ }^{26}$ In Le Signe=, Tarkos writes '[les mots] ils se mélangent dans un groupe, ils fusionnent dans un groupe, ce qui fait l'élément de sens, ce n'est plus le mot, c'est le groupe des mots 
fusionnées, c'est le tas, la boulette, la tirade, la masse terreuse, la bosse, l'idéogramme, le dessin. Le groupe des mots qui ont fusionné est mou, est tendre, est souple' (p. 29).

${ }^{27}$ In Pan, Tarkos clearly parodies Descartes's cogito, 'Je sais regarder la télévision/Je sais que regarder la télévision est la même chose que penser/Je pense'. Christophe Tarkos, Pan (Paris: P.O.L., 2000), p. 110.

${ }^{28}$ Christophe Tarkos, Caisses (Paris: P.O.L., 1998), p. 29.

${ }^{29}$ Samuel Beckett, En attendant Godot (Paris: Minuit, 1952), p. 60.

${ }^{30}$ Gherasim Luca, Le Chant de la carpe (Paris: José Corti, 1986), pp. 87-94.

${ }^{31}$ In contrast to Jérôme Game's agglutinative poetry, made up of jump cuts and where particles of syllables and consonants are consumed, words or phonemes are not truncated in Tarkos's poetry.

32 Tarkos, 'Poésie faciale' in Facial, 1 (1999), p. 4.

${ }^{33}$ See Julia Kristeva, 'Le Sujet en procés' in Artaud, ed. by P. Sollers (Paris: U.G.E., 10/18, 1973), pp. 43-108; and the recent synthesis on this question, L'Illisibilité en questions, ed. by B. Gorillot and A. Lescart (Paris: Presses universitaires du Septentrion, 2014).

${ }^{34}$ Tarkos, 'Ma langue est poétique' in Écrits Poétiques, p. 24.

${ }^{35}$ In Chaussure, Nathalie Quintane describes the micro-world of footwear. We can read for instance, 'Dans les vitrines des magasins, les chaussures ont les lacets noués [...]. A l'intérieur de chaque chaussure, l'étiquette du fabricant se déplace parfois, sans se décoller [...]. L'ongle du plus petit doigt de pied est souvent si petit, qu'il semble inexistant.' Quintane, Chaussure (Paris: P.O.L., 1997), n. p.

${ }^{36}$ Jean-Marie Gleize, A noir: poésie et littéralité (Paris: Seuil, 1992), p. 228.

37 'Idiôtès, idiot, signifie simple, particulier, unique; puis par extension sémantique dont la signification philosophique est de grande portée, personne dénuée d'intelligence, être dépourvu de raison. Toute chose, toute personne sont ainsi idiotes dès qu'elles n'existent qu'en elles- 
mêmes, c'est-à-dire incapable d'apparaître autrement que là où elles sont et telles qu'elles sont: incapable donc, et en premier lieu, de se refléter, d'apparaitre dans le double du miroir.' C. Rosset, Le Réel: Traité de l'idiotie (Paris: Minuit, 1986), p. 42.

${ }^{38}$ Tarkos, Caisses, p. 7.

${ }^{39}$ Stéphane Mallarmé, 'Lettre à H. Cazalis', in Correspondance: lettres sur la poésie, Euvres complètes, I, ed. by B. Marchal (Paris: Gallimard, 2003), p. 713.

${ }^{40}$ Tarkos, Caisses, p. 13.

${ }^{41}$ Barthes, Roland Barthes par Roland Barthes (Paris: Seuil, 1975), p. 54.

${ }^{42}$ Tarkos, Caisses, p. 9.

43 This Panentheism shows that Tarkos is resolutely Spinozist, as we shall see later in this article, because, for him, all that exists is a modification of the Substance.

${ }^{44}$ In the 1970s Prigent founded the journal TXT, whose critical approach can be compared to the Textualism of Tel Quel and which focused on the work of key figures of European historical avant-garde movements (Khlebnikov, Joyce, Artaud, Stein, Burroughs, Queneau and Pasolini). See TXT 1969-1993: une anthologie, ed. by C. Prigent (Paris: Christian Bourgois, 1995).

${ }^{45}$ Tarkos, 'Poésie faciale', p. 4.

${ }^{46}$ On the inexpressive diction and neutralisation of the subjectivity of the speaking voice in French contemporary poetry, see Dire la poésie?, ed. by J.-F Puff (Paris: Éditions Cécile Defaut, 2015).

${ }^{47}$ Tarkos, Le Signe=, p. 7.

48 'Ma langue est poétique' is exemplary in this respect. In this text, Tarkos plays on the double meaning of 'langue' (tongue and language): 'Ma langue est poétique, est naturelle, est sonore, est bruitée, est féconde, est douce, est inondée de soleil, ma langue a des sons d'herbe et d'été, l'herbe sèche de l'été, en été, l'herbe sèche est bruyante, bruisse et cingle, ce sont les herbes, les bruits viennent de l'herbe, ce sont des bruits d'herbes sèches, ma langue a les bruits sonores 
des herbes desséchées de l'été, les bruits répétitifs, incessants, les bruits de ma langue ne cessent pas, cinglent et se répètent, [...] les herbes bruissent, sifflent et cinglent, ma langue sèche siffle et cingle, ma langue sonore, ma langue herbeuse, ma langue de sons herbeux [...]. Ma langue est poétique et musicale, ma langue est imagée et musicale, ma langue est souple, étincelante et merveilleuse, ma langue aime jouer de la musique, elle vibre et fait vibrer chacun de ses mots qui rayonnent de leurs contours et qui viennent s'enchevêtrer si précisément qu'il ne reste aucune tache à son brillant poli. Elle fait le bruit de tous les sons des instruments de musique, elle fait le bruit de tous les sons des animaux et des phénomènes naturels. Ma langue est musicale. Ma langue est poétique.' Écrits poétiques, p. 48.

${ }^{49}$ Christian Prigent, 'La Voix-de-l'écrit' in Compile (Paris: P.O.L, 2011), p. 7.

${ }^{50}$ For Fónagy, two postulates are essential in the understanding of this phenomenon. First, 'la reproduction volontaire des symptômes vocaux d'une émotion signale la présence de cette émotion' and, second, 'les organes de la parole peuvent représenter, symboliser d'autres objets animés ou inanimés qui leur sont associés par la ressemblance ou une analogie formelle'. For example, a phoneme like [k], which requires a flexion of the sphincter, could potentially express anal pulsion, as in Artaud's glossolalia. See I. Fónagy, 'Les Bases pulsionnelles de la phonation. 1. Les sons', in Revue française de psychanalyse, 34 (1970), 101-36; see also 'Les Bases pulsionnelles de la phonation. 2. La prosodie' in Revue française de psychanalyse, 35 (1971), 543-91.

${ }^{51}$ See Michel Journiac, 'L'Objet du corps et le corps de l'objet' in Écrits (Paris: École Nationale Supérieure des Beaux-Arts, 2013), pp. 112-17.

${ }^{52}$ As Franck Leibovici suggests, in the 90s shrugging off the graphocentrism of the book was a way for many poets to escape from the traditional definition of poetry and to remove poetry from the page: 'au milieu des années 90, "quitter la poésie" ne pouvait donc vouloir dire qu’une chose, pour qui voulait continuer d'appliquer ce programme plus que centenaire: quitter le livre 
$[\ldots]$ cette attaque contre le livre devait donc s'exprimer dans des lieux autres que les librairies, et dans d'autres formats que le livre [...] mais pour porter, cette attaque devait nécessairement posséder une dimension publique.' Franck Leibovici, 'livre vs texte', in Spaces of the Book: Materials and Agents of the Text/Image Creation (20 $0^{\text {th }}-21^{\text {st }}$ centuries), ed. by I. Chol and J. Khalfa (Bern: Peter Lang, 2015), pp. 243-4. See also my article in the same volume, 'Un "X" d'entre les livres ou comment sortir du livre. Le Gigantexte $X$-Libris de Michèle Métail', pp. $211-26$.

53 Tarkos, L'Enregistré: performances/improvisations/lectures, ed. by P. Castellin (Paris: P.O.L., 2014), p. 96.

${ }^{54}$ Ibid. p. 95.

${ }^{55}$ See André Breton, Manifestes du surréalisme (Paris: Folio, 1985). See also Isidore Isou's vehement response to Breton's views on automatism in Histoire et rénovation de l'automatisme spirituel (Paris: R Altmann, 1967).

${ }^{56}$ Tarkos notes, ‘brut et non épais le poème à plat exactement étalé/sous les yeux dans toute sa longueur y/ s'embrasse pas d'intérieur le tout nu sans apprêt/ y se grate pas = moi je prend le poème à plat tout/nu comme il vient [...]'. 'Poésie faciale', Facial, p. 4.

${ }^{57}$ Christophe Tarkos, 'L'Histoire d'une performance' in L'Enregistré, p. 95.

${ }^{58}$ Gilles Deleuze and Félix Guattari, Qu'est-ce que la philosophie? (Paris: Minuit, 1991), pp. $119-200$.

${ }^{59}$ This was Manet's dictum inscribed in his letterhead. On the notion of the event in relationship to poetry, see Dominique Fourcade, Est-ce que j'peux placer un mot? (Paris: P.O.L., 2001), p. 59. 